\title{
IMPLEMENTASI COMPUTER BASED TEST (CBT) DI SEKOLAH MENENGAH KEJURUAN
}

\author{
Lidya Wati, Kasmawi, Sri Mawarni \\ Teknik Informatika \\ Politeknik Negeri Bengkalis. \\ lidyawati@polbeng.ac.id \\ mawipb@gmail.com \\ srimawarni@polbeng.ac.id
}

\begin{abstract}
ABSTRAK
Evaluasi pada suatu kegiatan pembelajaran sangatlah penting sebagai tolak ukur pemahaman bagi penerima materi pembelajaran. Pada jenjang pendidikan Sekolah Menengah Kejuruan (SMK) ataupun jenjang pendidikan lainnya sering melakukan evaluasi pembelajaran dalam jangka waktu per semester yang biasanya dilakukan minimal dua kali yaitu ujian tengah semester (UTS) dan ujian akhir semester (UAS). Pada umumnya sekolahsekolah dalam pelaksanaan UTS dan UAS menggunakan sistem ujian berbasis kertas (paper based test). Atikel ini membahas tentang implementasi CBT pada pelaksanaan ujian di SMK. Aplikasi ini mememiliki 3 hak akses yaitu admin sebagai pengelola aplikasi yang dapat menginput data ujian, siswa dan data guru, dan guru sebagai user yang dapat menginput soal ujian mata pelajaran yang dievaluasi, serta siswa sebagai peserta pada pelaksanaan ujian. Aplikasi ini tidak dapat menampilkan hasil ujian ketika siswa telah menjawab seluruh soal, namun dapat menampilkan rekapitulasi nilai per kelas per matapelajaran yang dapat dilihat oleh guru.
\end{abstract}

Kata kunci: computer based test, sekolah menengah kejuruan 


\section{Jurnal Batoboh, Vol 3 , No 1, Maret 2018 \\ Lidya Wati, Kasmawi, Sri Mawarni}

PENDAHULUAN

Evaluasi pada suatu kegiatan pembelajaran sangatlah penting sebagai tolak ukur pemahaman bagi penerima materi pembelajaran, pada konteks ini evaluasi berarti penilaian atau pengukuran. Penilaian adalah proses atau kegiatan yang sitematis dan berkesinambungan untuk mengumpulkan informasi tentang proses hasil belajar dalam rangka membuat keputusan-keputusan berdasarkan kriteria dan pertimbangan tertentu [1].

Penilaian dalam proses pembelajaran terdiri atas penilaian formatif dan sumatif [2]. Penilaian formatif dapat membantu pendidik untuk memantau perkembangan peserta didik dan hasil penilaian digunakan untuk meningkatkan kemampuan peserta didik dan mendeteksi kesulitan belajar peserta didik. Penilaian formatif dilakukan dalam bentuk ulangan harian atau penguasaan selama proses pembelajaran. Penilai sumatif dilakukan untuk mengetahui capaian peserta didik setelah proses pembelajaran berlangsung satu Hall 84 semester atau satu tahun pembelajaran dalam bentuk ujian semester, ujian kenaikan kelas atau ujian akhir.

Oleh karena itu setiap jenjang pendidikan yang ada akan selalu melakukan evaluasi pembelajaran yang biasnya dilakukan dalam bentuk ujian atau test. Pada jenjang pendidikan Sekolah Menengah Kejuruan ataupun jenjang pendidikan lainnya sering melakukan evaluasi pembelajaran dalam jangka waktu per semester yang biasanya dilakukan minimal dua kali yaitu evaluasi atau ujian pembelajaran pada triwulan pertama yang dikenal dengan Ujian Tengah Semester (UTS) dan evaluasi atau ujian pada triwulan kedua atau disebut Ujian Akhir Semester (UAS). Pada umumnya sekolah-sekolah dalam pelaksanaan UTS dan UAS menggunakan sistem ujian berbasis kertas (paper based test) dan koreksi hasil ujian masih secara 


\section{Jurnal Batoboh, Vol 3 , No 1, Maret 2018 \\ Lidya Wati, Kasmawi, Sri Mawarni}

manual yaitu guru membandingkan hasil ujian dengan kunci jawaban dan menandai hasil jawaban yang benar, hal ini dapat berpeluang terjadi kesalahan dalam mengkoreksi hasil ujian.

Untuk mengurangi resiko peluang terjadinya kesalahan koreksi dalam memberikan penilaian hasil ujian dapat dilakukan dengan menggantikan sistem ujian dari berbentuk paper based test kepada sistem computer based test (CBT) karena sistem CBT dapat menghasilkan proses penilaian yang objektif, teliti dan akurat.

\section{PEMBAHASAN \\ Konsep Dasar Sistem Informasi}

Pengertian sistem dalam berbagai bidang berbeda antara yang satu dengan yang lainnya, tapi konsep sistem mempunyai persyaratan umum, sistem mempunyai elemen, lingkungan, interaksi antar sistem, dan yang penting adalah sebuah sistem mempunyai tujuan yang akan dicapai. Menurut [3] "Sistem adalah kumpulan dari elemen-elemen yang berinteraksi untuk mencapai suatu tujuan tertentu".

Menurut McLeod Informasi Hal| 85 adalah data yang diolah menjadi bentuk lebih berguna dan lebih berarti bagi yang menerimanya. Informasi merupakan data yang telah di proses demikian rupa sehingga meningkatkan pengetahuan seseorang yang menggunakan. Sistem apapun tanpa informasi tidak akan berguna, karena sistem tersebut akan mengalami kemacetan dan akhirnya berhenti [4].

Informasi dapat berupa data mentah, data tersusun, kapasitas sebuah saluran informasi, dan sebagainya. Sumber dari informasi adalah data. Data merupakan bentuk jamak dari bentuk tunggal datum atau data-item.data adalah kenyataan yang menggambarkan suatu kejadiankejadaian dan kesatuan nyata. Kejadian-kejadian (event) adalah suatu yang terjadi pada saat yang tertentu. 


\section{Jurnal Batoboh, Vol 3 , No 1, Maret 2018}

Lidya Wati, Kasmawi, Sri Mawarni

Suatu informasi dikatakan bernilai bila manfaatnya lebih efektif dibandingkan dengan biaya untuk mendapatkannya dan sebagian besar informasi tidak tepat ditaksir

\section{Pengertian Computer Based Testing} (CBT)

\section{Computer Based Testing} merupakan ujian yang dikerjakan di komputer sehingga tidak memerlukan kertas, pena maupun pensil untuk menjawab pertanyaannya. Soalnya tertulis di komputer dan lembar jawabannya juga disediakan di komputer sehingga kita hanya tinggal mengklik jawaban yang benar maupun salah atau tinggal mengetik kalau menjawab pertanyaan essay.

Computer Based Testing ini banyak diimplementasikan di berbagai bidang seperti bidang pendidikan maupun di dunia kerja. Kalau di bidang pendidikan biasanya dipakai untuk menentukan berapa nilai tertinggi seorang siswa atau mahasiswa dalam menguasai satu mata pelajaran atau mata kuliah. Sedangkan di dunia kerja, Computer Based Testing digunakan untuk mengetahui kemampuan dasar dari Hal| 86 seorang pelamar pekerjaan sehingga mempermudah bagian HRD dalam melakukan seleksi terhadap calon karyawan [5]

\section{HASIL PERANCANGAN APLIKASI}

Hasil dari perancangan aplikasi CBT yang akan diimplementasikan untuk pelaksanaan UTS dan UAS pada SMK N 3 Bengkalis yang telah disesuaikan dengan kebutuhan pihak sekolah terdiri dari tiga sisi pengguna (user), yaitu dari sisi peserta ujian, guru dan dari sisi admin

\section{Tampilan Aplikasi untuk Peserta} Ujian

Peserta ujian yang menggunakan aplikasi CBT harus melakukan login terlebih dahulu, setelah login maka aplikasi akan memperlihatkan status ujian dan dapat melaksanakan ujian, adapun tampilan login, status peserta dan tampilan pada saat ujian ditunjukkan pada gambar 1, 2 dan 3 . 


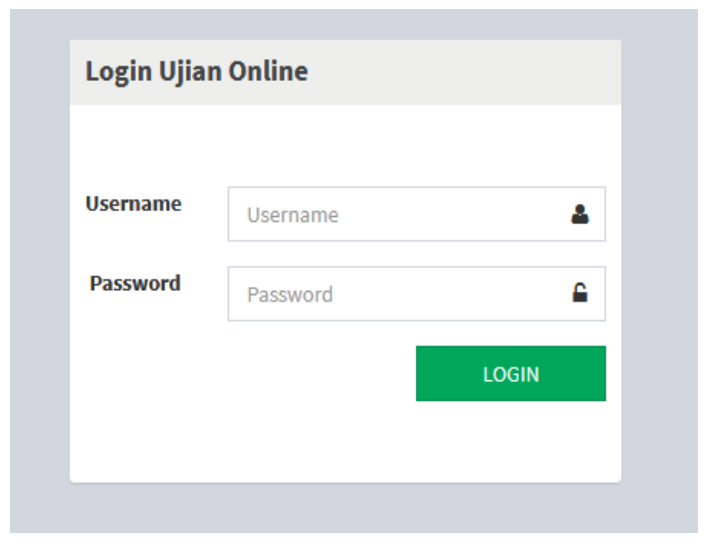

Gambar 1.

Tampilan halaman login

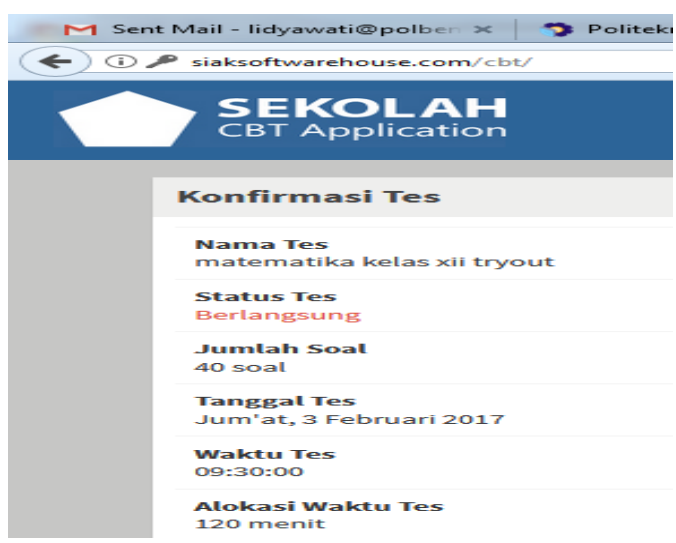

Gambar 2.

Tampilan status ujian

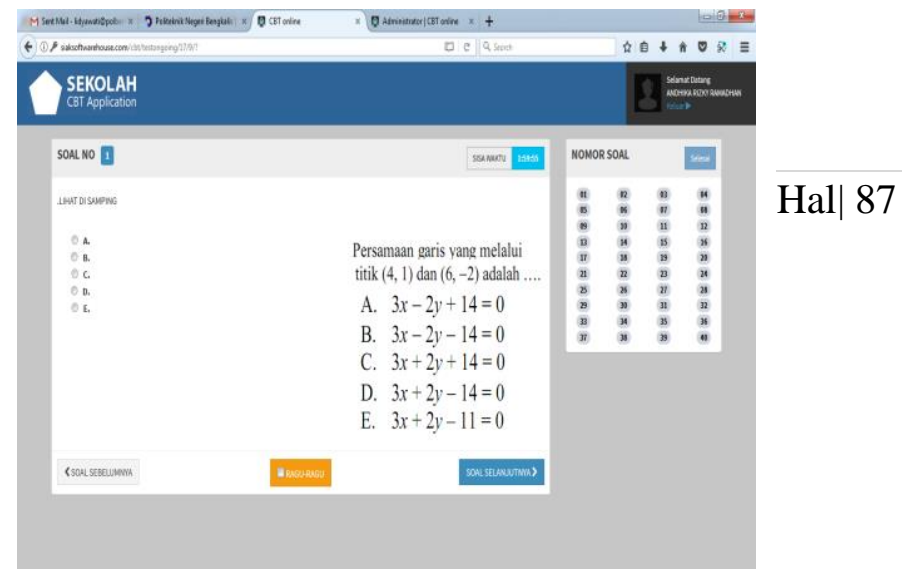

\section{Gambar 3.}

Tampilan pada saat ujian

\section{Tampilan Aplikasi untuk Admin}

Dalam mengimplementasikan sistem ujian berbasis komputer menggunakan aplikasi CBT ini, pengelolaan perangkat dokumen ujian pada aplikasi dilakukan oleh admin, yaitu pengolahan dan input data peserta ujian, soal, matapelajaran, dan kelas. Apun tampilan halaman admin, halaman peserta, halaman input soal, halaman matapelajaran, halaman kelas dan halaman nilai ditunjukkan pada gambar 4 sampai dengan gambar 9 . 


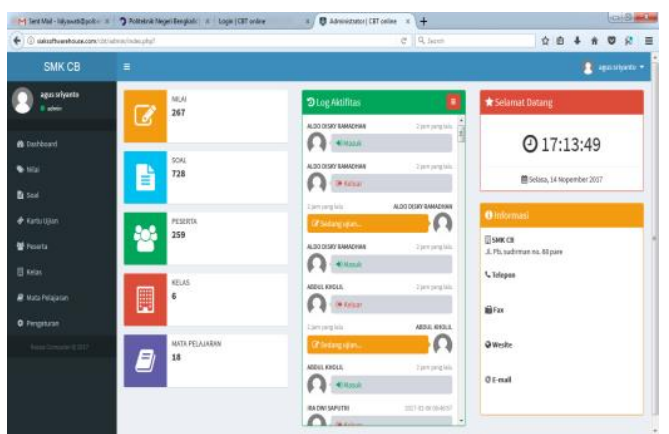

Gambar 4.

Tampilan halaman admin

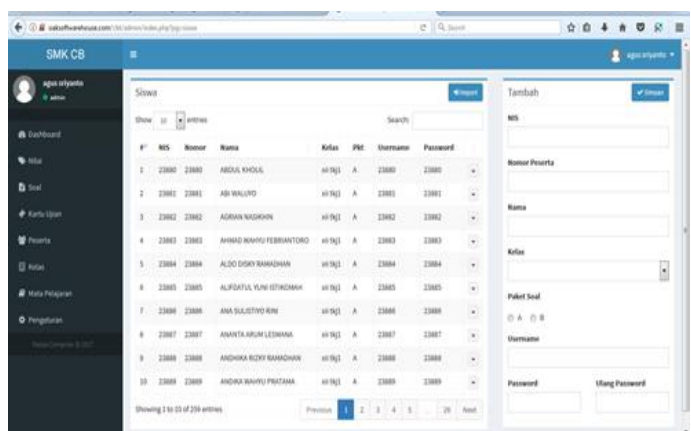

Hal| 88

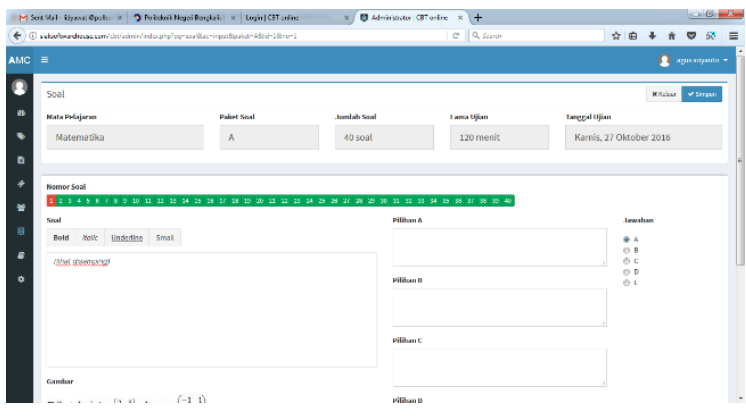

Gambar 6.

Tampilan halaman input soal

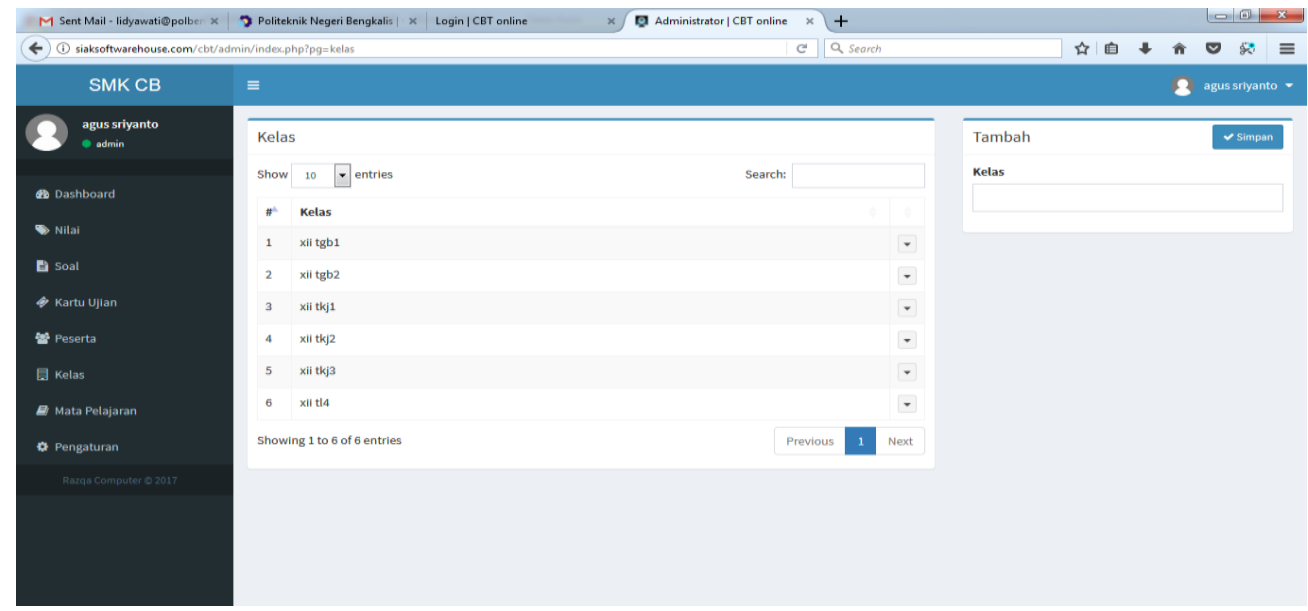

Gambar 7. Tampilan Halaman mata pelajaran 


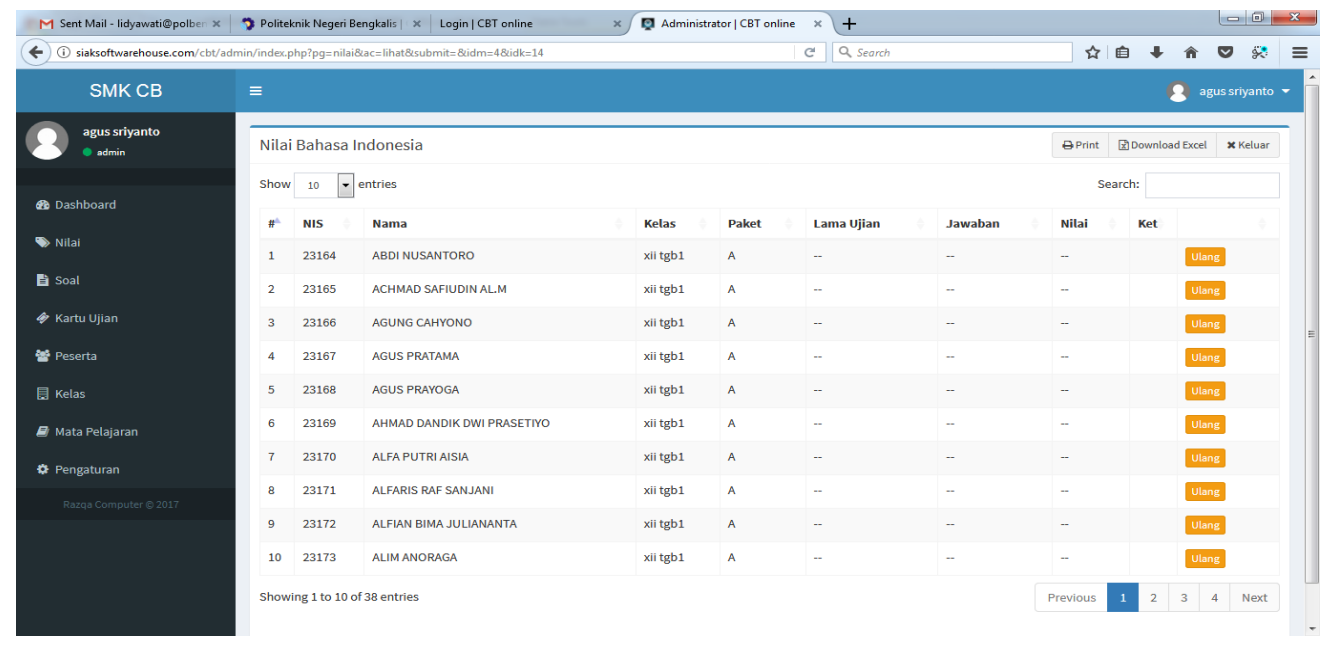

Gambar 8.Tampilan halaman kelas

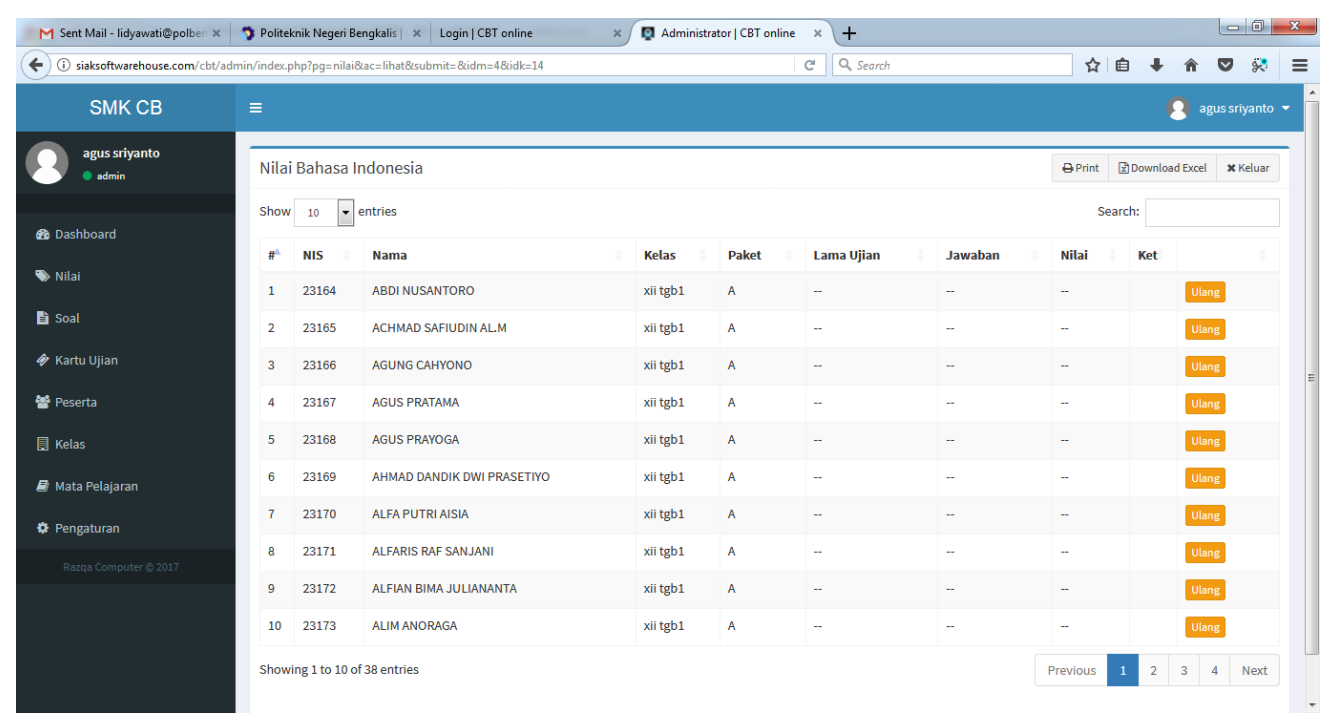

Gambar 9. Tampilan halaman Nilai

\section{Tampilan Aplikasi untuk Guru}

Selain admin, guru juga punya hak akses dalam pengelolaan aplikasi CBT ini dan guru dapat langsung dengan gambar 12.

menginput soal yang akan

dievaluasikan terhadap mata pelajaran yang akan diujikan kepada siswa, adapun tampilan aplikasi untuk guru dinyatakan pada gambar 10 sampai 


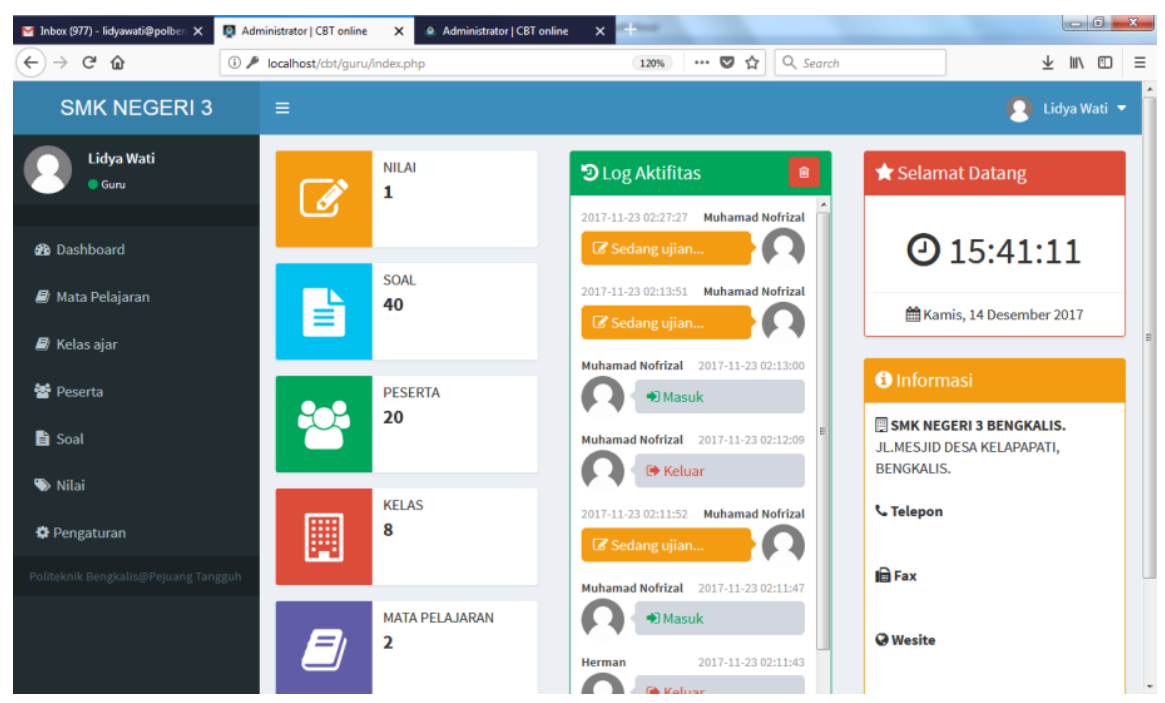

Gambar 10. Tampilan home untuk guru

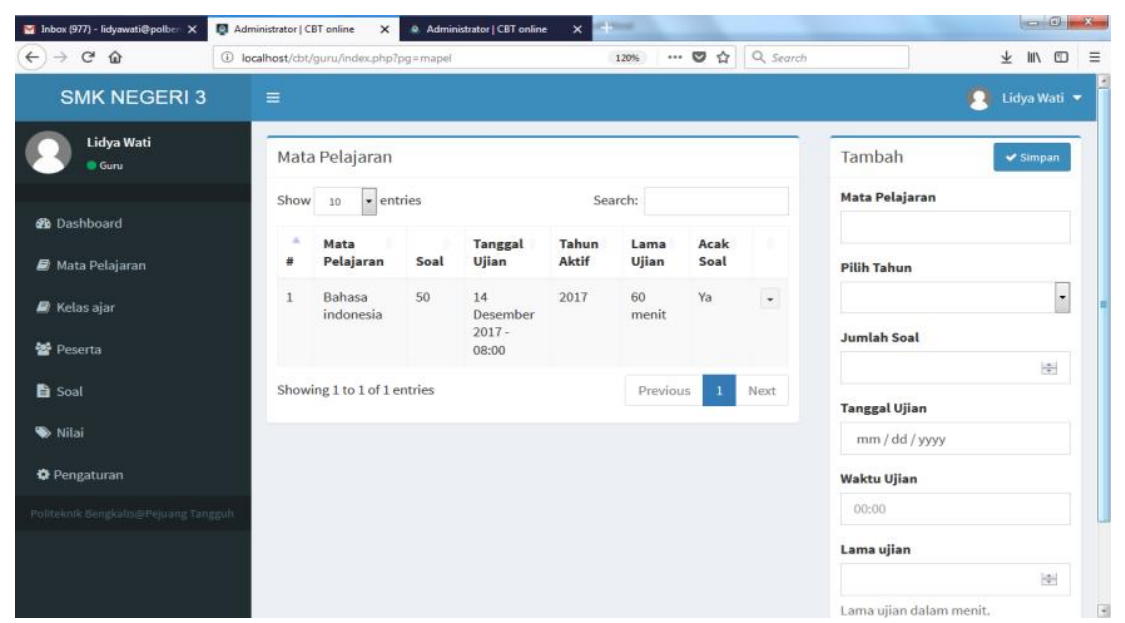

Gambar 11. Tampilan input matapelajaran untuk guru

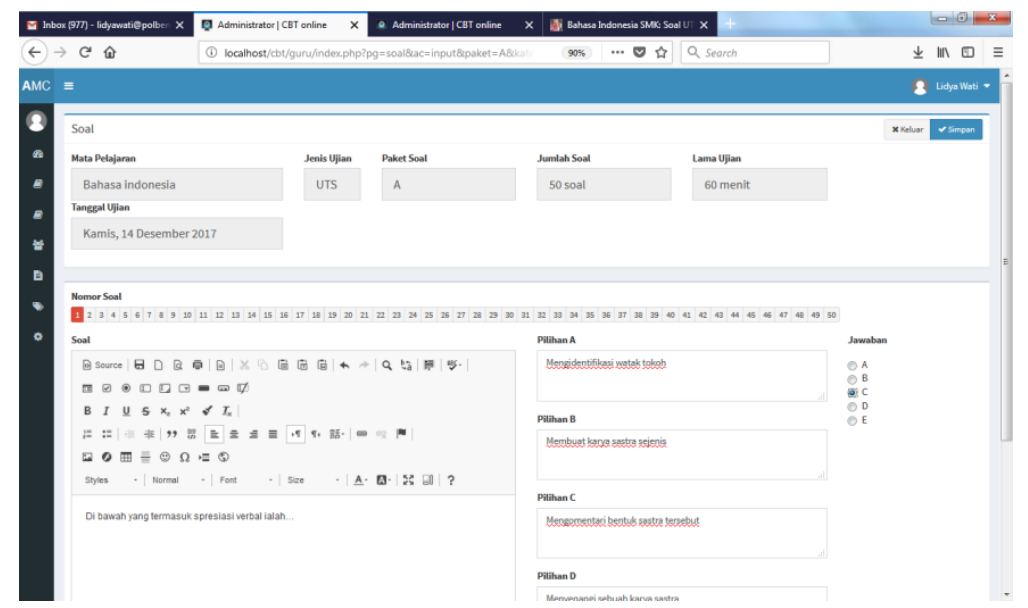

Gambar 12. Tampilan input soal 


\section{Jurnal Batoboh, Vol 3 , No 1, Maret 2018 \\ Lidya Wati, Kasmawi, Sri Mawarni}

\section{SIMPULAN}

Aplikasi Computer Based Test (CBT) dapat digunakan untuk UTS dan UAS pada SMKN 3 dan siswa dapat melakukan ujian dengan menggunakan sistem CBT yang dapat memudahkan guru dalam mengevaluasi hasil pembelajaran. Selain itu dengan pelaksanaan ujian menggunakan aplikasi CBT hasil koreksi dari jawaban ujian atau test akan lebih objektif, cermat dan akurat, karena setelah ujian siswa dapat langsung melihat hasil ujian atau score yang diperolah pada ujian yang dilaksanakan.

Karena sistem pada aplikasi CBT melakukan pengacakan soal, maka sebaiknya guru dalam menentukan soal untuk setiap materi yang diujikan hendaknya seimbang dalam menentukan komposisi soal tiap-tiap materi dan setiap variasi soal tiap materi mempunyai tingkat kesulitan yang sama. Jumlah komputer yang sangat terbatas pada SMKN 3, sehingga akan membutuhkan waktu yang lama untuk melaksanakan UTS dan UAS maka aplikasi ini dapat dikembangkan agar bisa diimplementasikan pada perangkat pendukung lainnya seperti smartphone berbasis android.

\section{KEPUSTAKAAN}

[1]. Zainal Arifin, 2012, Evaluasi Pembelajaran, PT. Remaja Rosdakarya, Bandung.

[2]. Nitko \& Susan, 2011, Educational Assesment of Students (Sixth Edition), Boston, M.A: Pearson Education Inc, publishing as Allyn \& Bacon

[3]. Hartono, Jogyanto, 2004, "Pengenalan Komputer ", Andi Offset, Yogyakarta.

[4]. Ivan Arifard Watung, dkk (2014). "Perancangan Sistem Informasi Data Alumni Fakultas Teknik Unsrat Berbasis Web". E-Journal Teknik Elektro dan Komputer Unsrat, ISSN 2301-8401.

[5]. Alhamidi, 2015, mengukur kemampuan bahasa inggris siswa SMA dengan menggunakan aplikasi CBT, Jurnal TEKNOIF 